\title{
SOIL CLASSIFICATION FROM RESISTIVITY AND P-WAVE SEISMIC VELOCITY WITH SUPPORT OF PARTICLE SIZE DISTRIBUTION (PSD) ANALYSIS
}

\author{
Abdullah Sanusi NH, Ismail NA*, Roslan IZ and Rosli N \\ Geophysics Section, School of Physics, Universiti Sains Malaysia, 11800 USM, Penang, Malaysia
}

\begin{abstract}
It is encouraged to use more than one geophysical method when conducting a field survey. It can help improve the subsurface interpretation and reduce the ambiguity inherent from inversion of geophysical method. 2D resistivity and seismic refraction methods were conducted to map and characterize the subsurface at Desasiswa Indah Kembara, Universiti Sains Malaysia, Pulau Pinang. The inversion profile shows that the subsurface has two zones with a resistivity value of 150-500 $\Omega \mathrm{m}$ (Zone A) and 5-100 $\Omega \mathrm{m}$ (Zone B). On the other hand, the subsurface velocity is $0.3-0.6 \mathrm{~km} / \mathrm{s}$ (Zone A) and $0.75-1.5$ $\mathrm{km} / \mathrm{s}$ (Zone B). However, the standard reference tables of resistivity and velocity value of soil and rock show variation and overlapping values that can affect the interpretation process. Therefore, additional information is important to support geophysical interpretation. Geological method such as particle size distribution (PSD) analysis (hydrometer analysis and mechanical sieving) was conducted to assist the interpretation. Percentage of clay, silt, and sand can be obtained through the PSD graph and used for soil classification. The value of total dissolved solids (TDS) and salinity of the area are also taken on-site for the saturated area with resistivity value of $20 \Omega \mathrm{m}$ at a depth of $2 \mathrm{~m}$. The area has TDS $(138-146 \mathrm{mg} / \mathrm{L})$, and salinity $(0.007 \mathrm{PSU})$ values indicating the fresh porefluid characteristics. Resistivity and seismic inversion profile manage to show the underlying subsurface layers. Results from PSD analysis also has supported the interpretation of the geology of the study area where Zone A was identified as silty sand, and Zone B is identified as silt and clay.
\end{abstract}

Keywords: 2D resistivity, particle size distribution, physical properties of soil, Seismic refraction

\section{Introduction}

Subsurface exploration requires a comprehensive assessment in determining site behaviour, rock depth, overburdening materials, and near-surface structures such as sinkholes, cavities, voids, faults, and boulders. Geological method may be applied concurrently with the geophysical method to promote the discovery of subsurface with a low cost and efficient method. Soil properties identification commonly involved soil sampling and laboratory experiments. Soil samples were obtained from the study area. Several tests related to the determination of properties of the soil were then conducted out by using the particle size distribution (PSD) analysis (mechanical sieving and hydrometer analysis). Geophysical methods are commonly used in subsurface investigation because it is much less harmful to the environment than an invasive method such as drilling. 2D resistivity and seismic refraction have become one of the most common methods used in shallow subsurface 
investigations. They have been implemented to delineate geological faults (Saetang et al. 2014; Nur Amalina et al. 2017; Nyabeze et al. 2018), finding groundwater (Moustafa et al. 2013, Ashraf et al. 2018; Azhar et al. 2019), and characterize subsurface and identifying the type of soil (Hazreek et al. 2015; Mad Said et al. 2015; Al-Heety and Shanshal 2016; Akip Tan et al. 2018). 2D resistivity method is susceptible to the distribution of electrical resistivity in the subsurface. It is an appropriate technique to yield information of the subsurface (Asry et al. 2012) and map areas with moderately complex geology (Griffiths and Barker 1993). On the other hand, a seismic refraction method is sensitive to the elastic properties of the rock (Riddle et al. 2010). It is usually used to determine shallow subsurface conditions or to estimate the depth to bedrock. Seismic methods are good at detecting vertical property changes. Using this method, we can determine the thickness of stratified layers of soil and rock that will contribute information about subsurface characteristics (Anomohanran 2013).

In this study, 2D resistivity and seismic refraction methods were performed on a flat-surface subsurface in Indah Kembara, Universiti Sains Malaysia (USM), Penang, to map the subsurface. 2D resistivity method was preferred because it is sensitive to the distribution of electrical resistivity of the subsurface, which also provides a good analysis for interpreting subsurface structures but is slightly less sensitive in detecting vertical property changes. In the meantime, seismic refraction is susceptible to soil elasticity and can imply heterogeneous horizontal and vertical variations in subsurface velocity (Abdelrahman et al. 2017) but faces difficulties in the resolution of lateral velocity changes. Also, the seismic velocity recovered from the refraction of the first break travel time inversion is often very smooth and does not recover sharp geological boundaries. Therefore, it is beneficial to use more than one geophysical method when conducting a field survey. The geophysical methods will complement each other to produce reliable information and improve the subsurface interpretation (Yusoh et al. 2018). Both methods may simultaneously generate results as a 2D image of the subsurface, making it much easier to interpret the data.

Geophysical methods are not preferred to be conducted alone for subsurface investigation (Benson \& Kaufmann 2003; Fraiha \& Silva 1994). The standard reference tables of resistivity and velocity value of soil and rock have often been difficult to use for interpretation due to the broad range of variation and overlapping values (Solberg et al. 2011). In order to strengthen the interpretation of the resistivity and seismic inversion, particle size distribution (PSD) analysis is expected to produce a significant result and can help to classify the type of soil. This study aimed to identify the resistivity, velocity and type of the soil with respect to the grain size, moisture content, and density of the soil sample. This study carried out a geophysical method along with a PSD analysis to minimize anomaly uncertainty interpretation, thereby improving the interpretation and conclusion of the results.

\section{Materials and methods}

\section{Study Area}

The selected area for this study is Pulau Pinang which is located in the North West of Peninsular Malaysia. Pulau Pinang is surrounded by granitic rocks (Kong 1999) and alluvium, consisting of clay, silt and sand. It is categorized under Bukit Bendera and Sungai Ara formation, categorized according to age, mineralogy, and textures. This study area was located at Universiti Sains Malaysia (USM), Pulau Pinang (Figure 1). The study area in Indah Kembara is flat-lying ground and is near to a large 
drain. The length of the resistivity line is $40 \mathrm{~m}$ with $1 \mathrm{~m}$ electrode spacing, and the length of the seismic line is $23 \mathrm{~m}$ with $1 \mathrm{~m}$ geophone spacing. There are seven shot points, five inline shot points and two offsets. The center of the resistivity line $(20 \mathrm{~m})$ and seismic line $(12 \mathrm{~m})$ are at the same point. The position of both resistivity and seismic lines are shown in Figure 1.

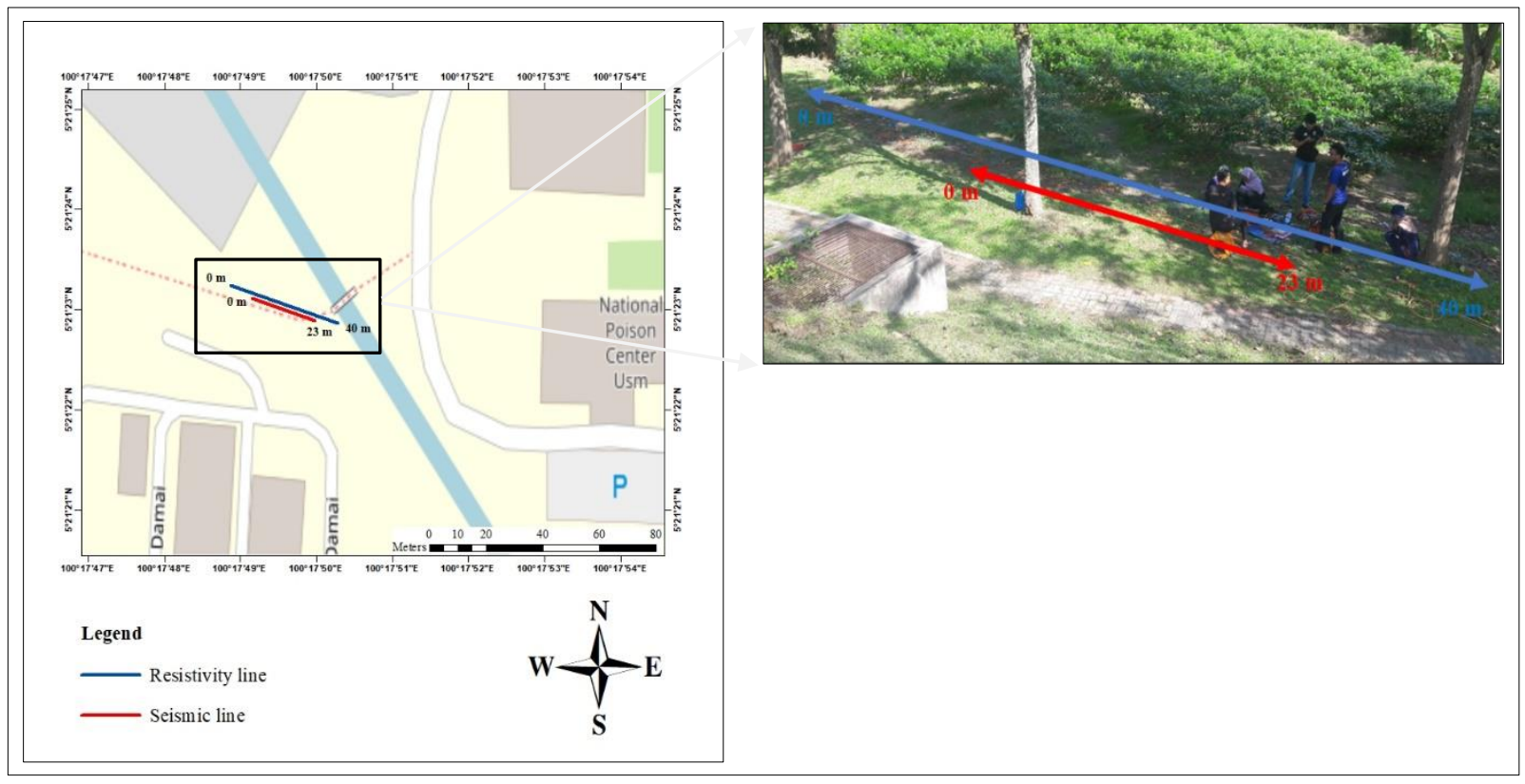

Figure 1: Resistivity line (blue) and seismic line (red) at Indah Kembara, Universiti Sains Malaysia, Pulau Pinang.

\section{D Resistivity Method}

2D resistivity method is used in imaging subsurface structures from electrical resistivity measurements made at the surface or by electrodes. Resistivity survey follows Ohm's Law that determines the current flow in the ground (Loke 2004). Current was injected through $\mathrm{C} 1$ and $\mathrm{C} 2$, then potential difference $(\Delta V)$ at $\mathrm{P} 1$ and $\mathrm{P} 2$ were calculated. Electrode carries current (I), which is measured in Amperes (A), and the potential difference created at any point in a medium is given as,

$$
\Delta V=R I
$$

where $\Delta V$ is a potential difference, $\mathrm{R}$ is resistance, and I is current. Subsurface resistivity value can be estimated from the apparent value through inversion method. A 2D model with a smooth variation of resistivity value can be constructed using this method. This method's susceptibility towards the fluid motion through the subsurface and resistivity changes in the subsurface is affected by mineral content, porosity, saturation of water, and rocks' salinity. In this study, this method was conducted with 41 electrodes using a pole-dipole array. The length of the survey line was $40 \mathrm{~m}$ with $1 \mathrm{~m}$ electrode spacing. Pole-dipole array was selected because it has good horizontal coverage and good signal strength and can give deeper subsurface coverage compared to the other configurations (Loke 2004). This array can provide better spatial resolution images and recover to a deeper depth even with a limited number of electrodes. 


\section{Seismic Refraction Method}

The other method chosen for this study is seismic refraction. A seismic refraction method can determine the velocity distribution down a subsurface using seismic wave, which will be detected by geophone and recorded on a seismograph. A seismic refraction method follows Snell's law of light and phenomenon of critical incidence,

$$
\frac{\sin \alpha}{\sin \beta}=\frac{V_{1}}{V_{2}}
$$

Critical incidence occurs when $\beta=90^{\circ}$. So,

$$
\sin \alpha=\frac{V_{1}}{V_{2}}
$$

where $V_{1}$ is the velocity of a first layer, and $V_{2}$ is the velocity of a second layer. The seismic refraction method involved the analysis of $\mathrm{p}$-wave, $\mathrm{V}_{\mathrm{p}}$ traveltime. The depth of the subsurface can be calculated and can determine the velocity of the soil layer. The layers of soil in p-wave velocity is determined using intercept-time or crossover distance formula as shown by,

$$
\begin{aligned}
& Z=\frac{t_{i}}{2} \frac{V_{2} \cdot V_{1}}{\sqrt{V_{2}^{2}-V_{1}^{2}}} \\
& Z=\frac{X_{c}}{2} \sqrt{\frac{V_{2}-V_{1}}{V_{2}+V_{1}}}
\end{aligned}
$$

First break arrival times are picked on all shot records. The travel times can be inverted to obtain the estimate of seismic velocity distribution. The seismic refraction method was conducted on the same line as the $2 \mathrm{D}$ resistivity method from the North to South area. The seismic refraction survey line was $23 \mathrm{~m}$ long with $1 \mathrm{~m}$ geophone spacing. A sledgehammer was chosen as the source to produce a seismic wave in this study. A total of eight shot points were performed to obtain seismic data for interpretation. Five in-line shot points and two offset shot points (one forward and one reverse) were performed. Forward and reverse shots were conducted to assess the consistency of the velocities and the geometry of the seismic refractors. All shot points were performed to obtain a high quality of seismic data for interpretation. Seismic refraction data were processed, and travel-time curves were generated to produce 2D seismic velocity depth profiles characterizing the subsurface layers. This profile was produced using travel time first break data and geophone distance as parameters to calculate each layer's $V_{p}$ value and thickness by inversion. Bulk and shear stiffness or compliance in the subsurface influence the velocity, attenuation and impedance of the seismic wave (Hickey et al. 2009). Other factors that affected the velocity of the subsurface are the lithology, the porosity, the fluid saturation, the pressure, elastic parameters of rock and density (Yilmaz 2001).

\section{Particle Size Distribution (PSD) Analysis}

PSD analysis can be used to segregate the dry mass of the soil into specified particle size categories. This method is applied to distinguish the types of soil because the particle size affects the frequency at which water or other fluid percolates through the soil. The PSD curve would show details on the percentage of gravel, sand, silt, and clay found in the soil's dry mass predicated on the size 
classification of particles. Two sections of the PSD analysis are hydrometer analysis and mechanical sieving. Hydrometer analysis is used to determine the fluid density and percentage of soil particles finer than No. $200(75 \mu \mathrm{m})$ sieve and larger than $0.2 \mu \mathrm{m}$ sieve at a particular time using a hydrometer. Soil samples were put into a measuring cylinder filled with Sodium Hexametaphosphate (Na6[(PO3)6]) and distilled water (Figure 2(a)). Readings of hydrometer were taken at interval time for 24 hours. Mechanical sieving analysis is used to mechanically sieve the leftover portions in a series of sieve fractions using $6.3 \mathrm{~mm}, 4.75 \mathrm{~mm}, 2.0 \mathrm{~mm}, 1.18 \mathrm{~mm}, 600 \mu \mathrm{m}, 425 \mu \mathrm{m}, 300 \mu \mathrm{m}, 212$ $\mu \mathrm{m}$, and $75 \mu \mathrm{m}$ within 10 minutes. The mass of the portion retained on each sieve is recorded. The results of the hydrometer and mechanical sieving analyses will be used to plot the PSD graph. Figure 2 (b) shows the set-up of the sieving method. Table 1 shows the list of equipment used for the mechanical sieving process. Table 2 is the summary of soil classification for PSD analysis by Santamarina et al. (2001).

(a)

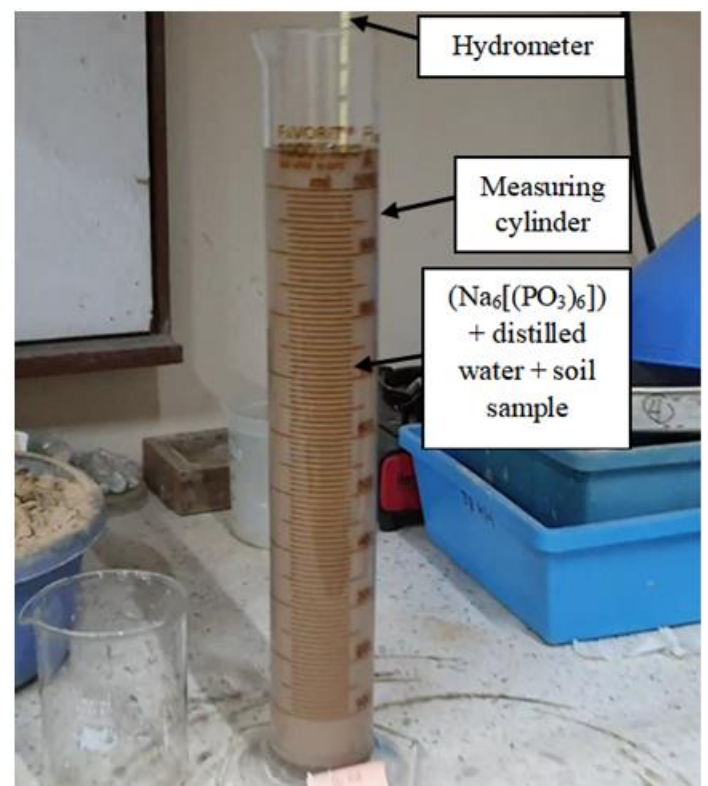

(b)

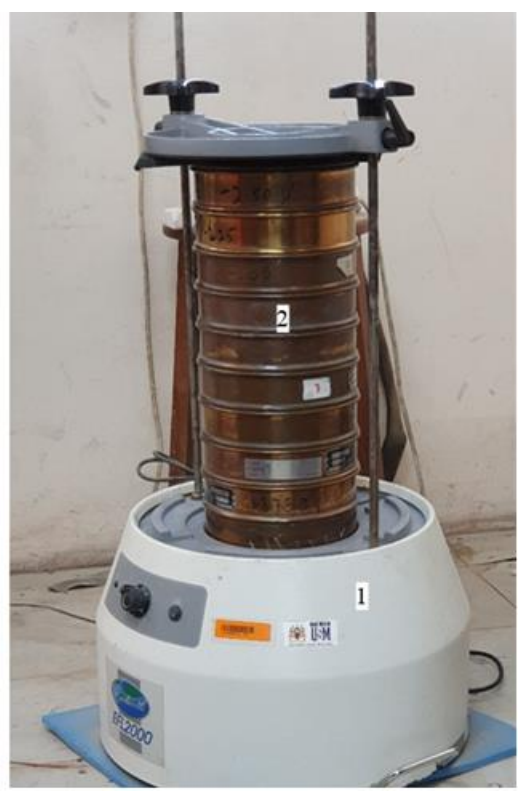

Figure 2: (a) A measuring cylinder of soil sample in a solution of Sodium Hexametaphosphate (Na6[(PO3)6]) and distilled water with hydrometer. (b) Stack of sieve according to size.

Table 1: The list of equipment as labelled in Figure $2(b)$.

\begin{tabular}{llc}
\hline No & \multicolumn{1}{c}{ Equipment } & Quantity \\
\hline 1 & Endecotts Laboratory Shaker EFL200 & 1 \\
2 & Endecotts Laboratory Test Sieves & 1 \\
$1.1 / 4$ in $(6.3 \mathrm{~mm})$ & 1 \\
2. No $4(4.75 \mathrm{~mm})$ & 1 \\
3. No $10(2.0 \mathrm{~mm})$ & 1 \\
4. No $16(1.18 \mathrm{~mm})$ & 1 \\
5. No $30(0.6 \mathrm{~mm})$ & 1 \\
6. No $40(0.425 \mathrm{~mm})$ & 1 \\
7. No $50(0.3 \mathrm{~mm})$ & 1 \\
8. No $70(0.212 \mathrm{~mm})$ & 1 \\
9. No $200(0.075 \mathrm{~mm})$ & 1 \\
10. Pan & \\
\hline
\end{tabular}


Table 2: Summary of soil classification (Santamarina et al. 2001).

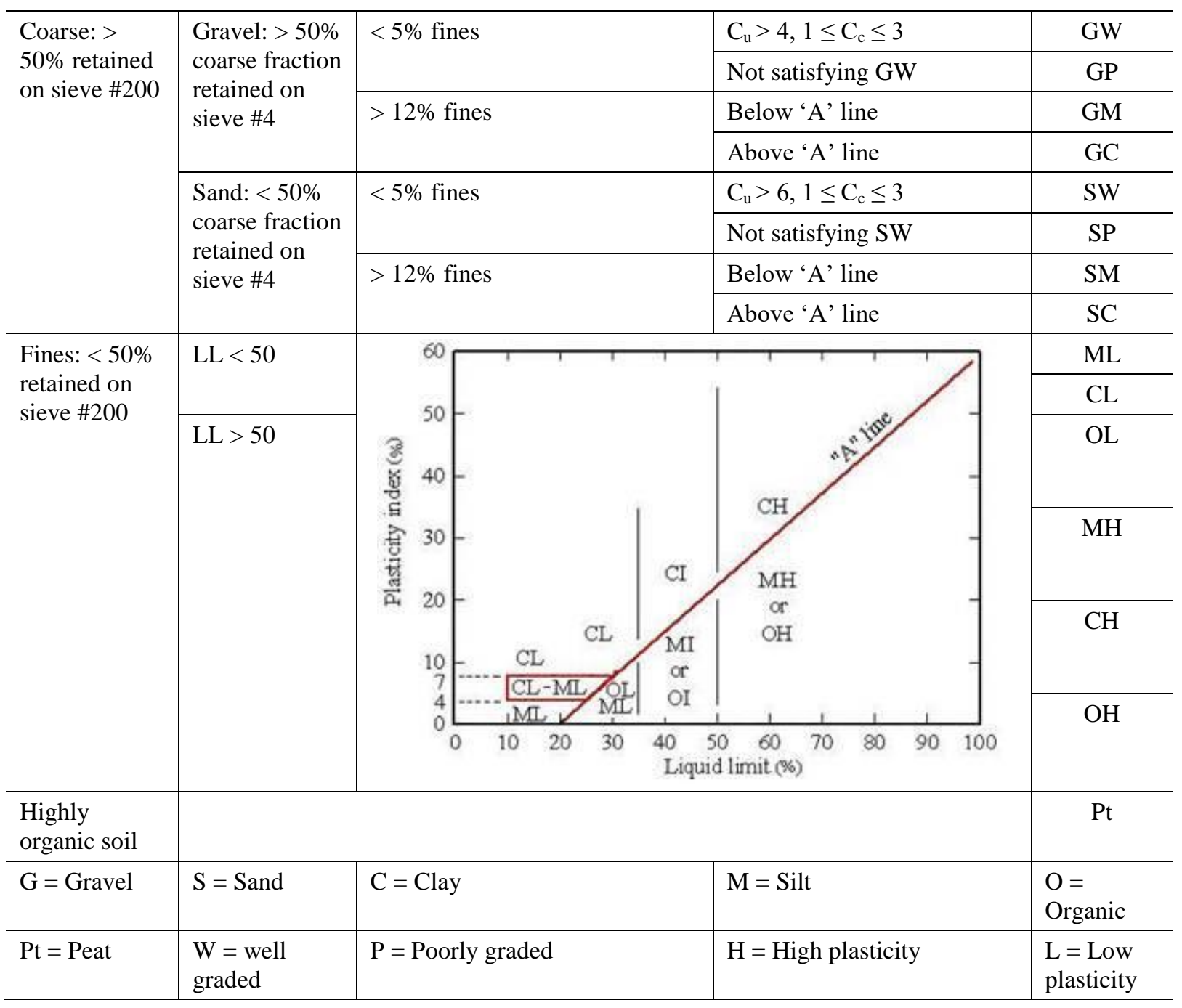

\section{Results and discussion}

The results obtained from the inversion of resistivity and seismic refraction are shown in Figure 4. The resistivity inversion reveals two subsurface zones (Figure 3 (a)). Zone A displays a high resistivity value between $150-500 \Omega \mathrm{m}$ at $3 \mathrm{~m}$ and also at 7-10 $\mathrm{m}$ depth. Zone B displays a low resistivity value $(5-100 \Omega \mathrm{m})$ from $3 \mathrm{~m}$ to $7 \mathrm{~m}$ depth. Inversion of seismic refraction is shown in Figure 3 (b). According to seismic velocity values, the subsurface of the study area was divided into two zones. Zone A has a low velocity value ranging from about $0.3-0.6 \mathrm{~km} / \mathrm{s}$, and a thickness reached $3 \mathrm{~m}$ depth. Zone $\mathrm{B}$ was characterized by high velocity value ranging from approximately $0.75-1.5$ $\mathrm{km} / \mathrm{s}$ and a thickness from $3 \mathrm{~m}$ to $10 \mathrm{~m}$. More dense and saturated soil may explain the decrease in resistivity and seismic velocity with depth. In the upper zones, these high resistivity and low resistivity values are the characteristics of more weathered soil. Besides, grain size, density, permeability, and water saturation level could affect the resistivity and seismic velocity values in this subsurface. 

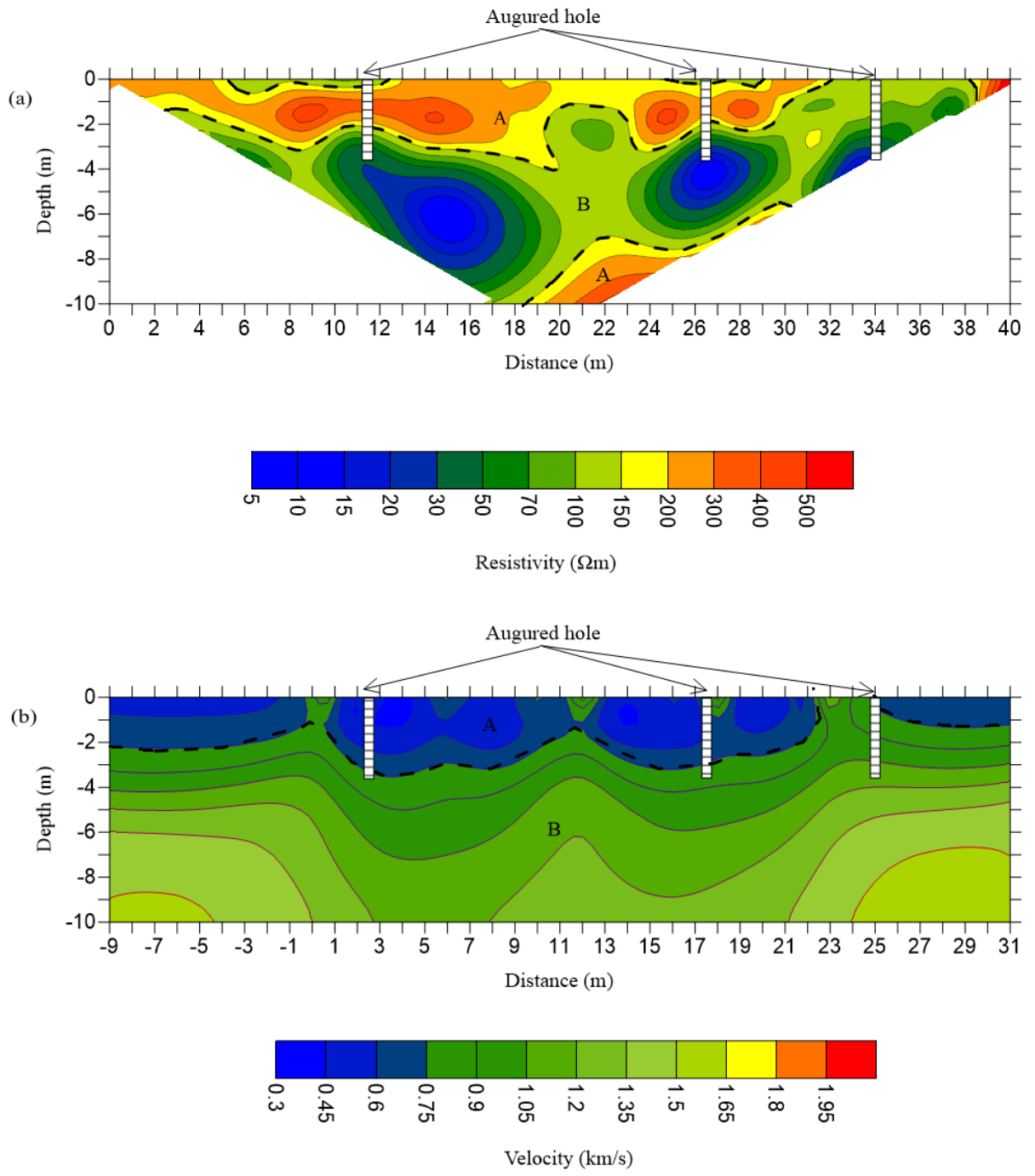

Figure 3: Inversion (a) resistivity and (b) seismic profile and the location of the augured holes on the profile lines.

PSD analysis was conducted to classify the type of soil. Soil samples were collected at a distance of $11.5 \mathrm{~m}$ on the resistivity line. An augured hole was drilled up to $3.6 \mathrm{~m}$ in depth. Figure 4 shows PSD graphs of soil samples taken at a depth of $0.8 \mathrm{~m}, 1.8 \mathrm{~m}, 2.8 \mathrm{~m}$, and $3.6 \mathrm{~m}$. The soil classification of each sample was deduced based on Santamarina et al. (2001). Figure 4 (a) shows a PSD graph of a soil sample taken at $0.8 \mathrm{~m}$ depth. From this graph, the percentage of gravel, sand, and silt and clay was $8.18 \%, 41.89 \%$ and $49.93 \%$, respectively. This sample was classified as clayey sand. Figure 4 (b) shows a PSD graph of a soil sample taken at $1.8 \mathrm{~m}$ depth. The percentage of gravel, sand, and silt and clay were $12.25 \%, 52.38 \%$, and $35.38 \%$, respectively. It was identified as silty sand. Figure 4 (c) shows a PSD graph of a soil sample taken at $2.8 \mathrm{~m}$ depth. This soil sample was dominated by finegrained soil $(93.09 \%)$ and a small percentage of coarse grain soil, sand $(6.07 \%)$ and gravel $(0.84 \%)$. Therefore, it was identified as clay. Figure 4 (d) shows a PSD graph of a soil sample taken at $3.6 \mathrm{~m}$ depth. The percentage of gravel, sand, and silt and clay are 1.34\%, 43.05\%, and 55.6\%, respectively. It was identified as silt. Table 3 shows the summary of the PSD analysis. 

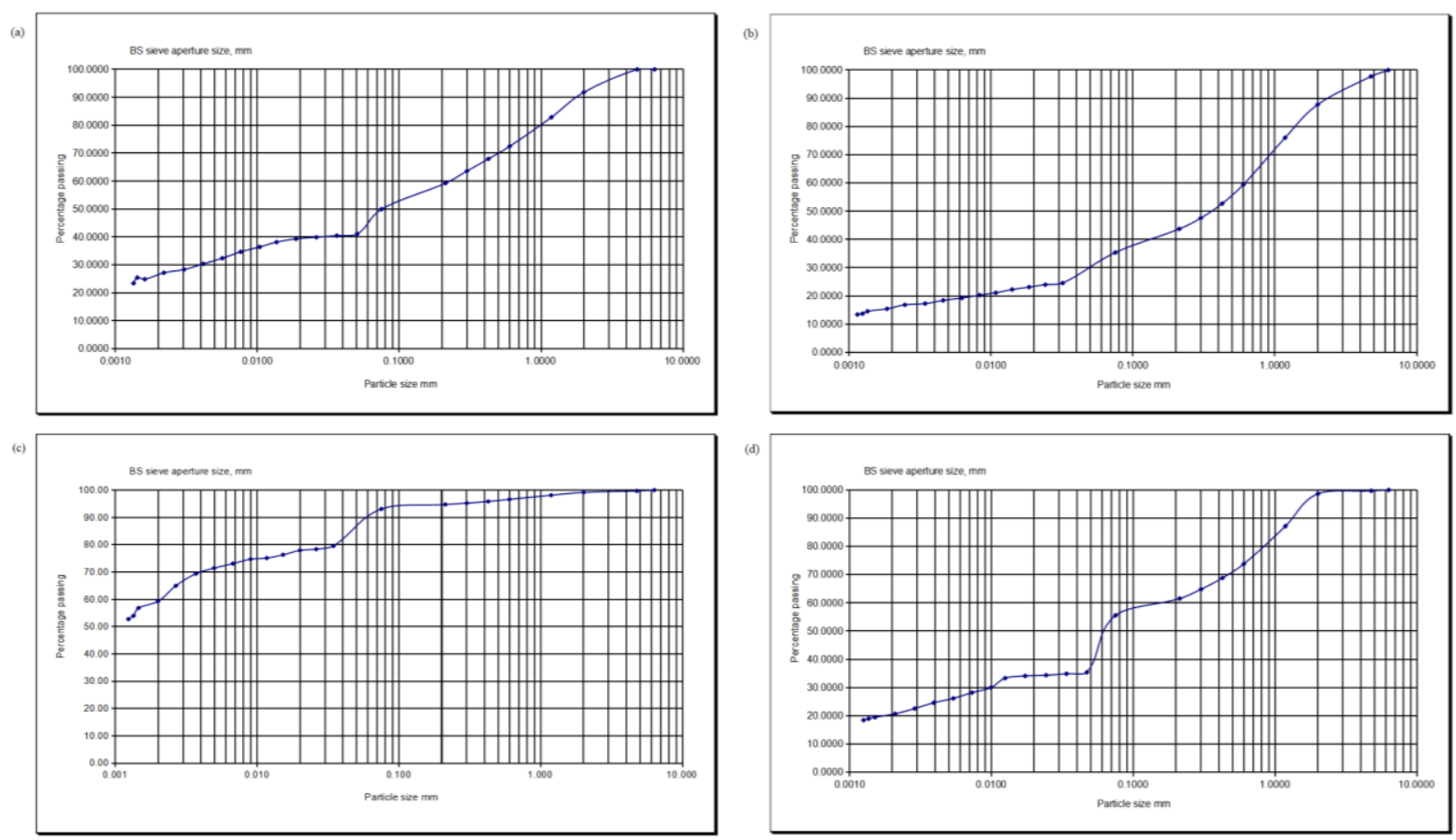

Figure 4; PSD analysis graph for soil sample of the study area at a depth of (a) $0.8 \mathrm{~m},(\mathrm{~b}) 1.8 \mathrm{~m},(\mathrm{c}) 2.8 \mathrm{~m}$, and (d) $3.6 \mathrm{~m}$.

Soil with a dominant fine-grained soil is usually has a low resistivity but high velocity value. At a depth of $1.8 \mathrm{~m}$ (Zone A), coarse-grained soil has a higher percentage of gravel and sand with $12.25 \%$ and $52.38 \%$, respectively, while soil at a depth of $2.8 \mathrm{~m}$ (Zone B) consists mainly of fine-grained soil such as silt and clay (93.2\%). Fine-grained soil allows the current to flow easily, thus produce a low resistivity value compared to coarse-grained soil. A seismic wave transmits energy by the vibration of soil particles in different directions in the direction of the wave propagation. Soil with high fine grain is more compact and allow the seismic wave to transmit energy easily through the subsurface, thus producing high P-wave velocity. Commonly, high resistivity and low velocity are expected if the density of soil is high. Coarse-grained soil has a higher mass compared to fine soil, thus denser. The soil sample is denser at a depth of $1.8 \mathrm{~m}\left(2.55 \mathrm{~g} / \mathrm{ml}^{3}\right)$ than the soil sample at a depth of $2.8 \mathrm{~m}(2.00$ $\mathrm{g} / \mathrm{ml}^{3}$ ). Thus, region at $1.8 \mathrm{~m}$ depth has higher resistivity and low velocity value due to large amounts of sand (51.58\%) and gravel (11.41\%). However, despite having a high soil density of $2.55 \mathrm{~g} / \mathrm{ml}^{3}$ at $3.6 \mathrm{~m}$ depth, the region reveals a low resistivity and high velocity value. It is also possibly due to the greater moisture content that gives out a higher density of soil. The presence of more water in the fine-grained soil (clay and silt) raises the soil's moisture content (40.28\%) and creates a low resistivity but high velocity region.

Fine-grained soil composition has low permeability as it has a greater capacity to hold more water. Meanwhile, soil consisting of coarse-grained soil such as gravel with sand has minimum water content (Sulaiman et al. 2017) due to its higher permeability. Coarse grain soil has a lower capability of absorbing more water and allows the water to percolate through easily. At a depth of $1.8 \mathrm{~m}$, which is considered zone $\mathrm{A}$, has a higher percentage of coarse-grained soil (62.99\%) results in low moisture content (15\%). At a depth of $2.8 \mathrm{~m}$, which is zone B, the percentage of fine-grained soil is the highest (93.2\%), which results in high moisture content (39.68\%). Therefore, zone B has a lower resistivity and higher velocity value, while zone A has higher resistivity and lower velocity value. Augered holes 
were drilled at $27 \mathrm{~m}$ and $35 \mathrm{~m}$ on resistivity line up to $3 \mathrm{~m}$ depth. Direct measurement on the sample was taken on site. The region below the depth of $2 \mathrm{~m}$ is also known as a fresh pore-fluid environment. The region has total dissolved solid (TDS) and salinity values of fresh pore fluid characteristics (138$146 \mathrm{mg} / \mathrm{L}$ and $0.07 \mathrm{PSU}$ respectively) (Table 4).

Table 3: Summary of PSD analysis.

\begin{tabular}{|c|c|c|c|c|c|c|c|c|}
\hline \multirow{2}{*}{$\begin{array}{l}\text { Location of } \\
\text { augered hole on } \\
\text { resistivity line } \\
\text { (m) }\end{array}$} & \multirow[t]{2}{*}{ Soil sample } & \multirow{2}{*}{$\begin{array}{l}\text { Depth } \\
\text { of soil } \\
\text { sample } \\
\text { (m) }\end{array}$} & \multicolumn{4}{|c|}{ PSD analysis } & \multirow{2}{*}{$\begin{array}{l}\text { Moisture } \\
\text { content, w } \\
(\%)\end{array}$} & \multirow{2}{*}{$\begin{array}{l}\text { Density } \\
(\mathrm{g} / \mathrm{ml})\end{array}$} \\
\hline & & & $\begin{array}{l}\text { Silt and } \\
\text { clay } \\
(\%)\end{array}$ & $\begin{array}{l}\text { Sand } \\
(\%)\end{array}$ & $\begin{array}{l}\text { Gravel } \\
(\%)\end{array}$ & $\begin{array}{l}\text { Soil } \\
\text { type }\end{array}$ & & \\
\hline \multirow[t]{4}{*}{11.50} & & 0.80 & 49.93 & 41.89 & 8.18 & $\begin{array}{l}\text { Clayey } \\
\text { sand }\end{array}$ & 20.48 & 2.50 \\
\hline & & 1.80 & 35.38 & 52.38 & 12.25 & $\begin{array}{l}\text { Silty } \\
\text { sand }\end{array}$ & 15.00 & 2.55 \\
\hline & & 2.80 & 93.09 & 6.07 & 0.84 & Clay & 39.68 & 2.00 \\
\hline & & 3.60 & 55.6 & 43.05 & 1.34 & Silt & 40.28 & 2.55 \\
\hline
\end{tabular}

Table 4: TDS and salinity value of soil of study area.

\begin{tabular}{cccc}
\hline $\begin{array}{l}\text { Location of augered hole on } \\
\text { resistivity line }(\mathrm{m})\end{array}$ & Depth of soil sample $(\mathrm{m})$ & TDS $(\mathrm{mg} / \mathrm{L})$ & Salinity (PSU) \\
\hline 26.5 & 1.5 & 176 & 0.08 \\
& 2.0 & 145 & 0.07 \\
2.5 & 139 & 0.07 \\
34 & 2.0 & 143 & 0.07 \\
& 2.5 & 138 & 0.07 \\
& 3.0 & 146 & 0.07 \\
\hline
\end{tabular}

\section{Conclusion}

Combination of two geophysical parameters which is resistivity and seismic velocity with aid of geotechnical method (PSD analysis) were successfully classified the soil in the study area. Two zones were identified where zone A is silty sand and zone B is silt and clay. Silty sand has higher resistivity but lower p-wave velocity compared to silt and clay due to its larger grain size, higher density, higher permeability and low soil moisture content. The PSD analysis has significantly minimize the uncertainty and strengthened the interpretation of resistivity and seismic inversion. Combination of two or more geophysical/geotechnical methods is auspicious in mapping the complex subsurface. 
Further research can be conducted with other geophysical methods and study other parameters for more accuracy in soil classification.

\section{Acknowledgements}

Special thanks to Fundamental Research Grant Scheme FRGS/1/2018/STG09/USM/02/2 for funding this research and USM Geophysics group for their contribution during data acquisition. Funding from postgraduate studies' account, School of Physics, Universiti Sains Malaysia.

\section{References}

Abdelrahman, K., Alfaifi, H., Ibrahim, E., Al-Qadasi, B., Alumindan, S. (2017). Detection of a shallow groundwater aquifer using seismic refraction tomography: A case study of Wadi Showat, Abha District, Southern Saudi Arabia. In: SEG international exposition and $87^{\text {th }}$ annual meeting, pp 5418-5421. https ://doi.org/10.1190/ segam 2017-17738 517.1

Akip Tan, S.N.M., Md Dan, M.F., Tonnizam, M.E., Saad, R., Madun, A., Hazreek, Z.A.M. (2018). Interpretation of $2 \mathrm{D}$ resistivity with engineering characterisation of subsurface exploration in Nusajaya Johor, Malaysia. Journal of Physics: Conference Series, 995(1), 2-8. https://doi.org/10.1088/1742-6596/995/1/012078

Al-Heety, A.J.R., Shanshal, Z.M. (2016). Integration of seismic refraction tomography and electrical resistivity tomography in engineering geophysics for soil characterization. Arabian Journal of Geosciences, 9(1), 1-11. https://doi.org/10.1007/s12517-015-2116-9

Anomohanran, O. (2013). Seismic refraction method: A technique for determining the thickness of stratified substratum. American Journal of Applied Sciences, 10(8), 857-862. https://doi.org/10.3844/ajassp.2013.857.862

Ashraf, M.A.M., Yusoh, R., Sazalil, M.A., Abidin, M.H.Z. (2018). Aquifer characterization and groundwater potential evaluation in sedimentary rock formation. Journal of Physics: Conference Series, 995(1). https://doi.org/10.1088/1742-6596/995/1/012106

Asry, Z., Samsudin, A.R., Yaacob, W.Z., Yaakob, J. (2012). Groundwater investigation using electrical resistivity imaging technique at groundwater investigation using electrical resistivity imaging technique at Sg. Udang, Melaka, Malaysia. Bulletin of the Geological Society of Malaysia, 58(December), 55-58. https://doi.org/10.7186/bgsm58201209

Azhar, A.S., Latiff, A.H.A., Lim, L.H., Gödeke, S.H. (2019). Groundwater investigation of a coastal aquifer in Brunei Darussalam using seismic refraction. Environmental Earth Sciences, 78(6), 1-17. https://doi.org/10.1007/s12665-019-8203-6

Benson, R.C., Yuhr, L., Kaufmann, R.D. (2003). Some considerations for selection and successful application of surface geophysical methods. Proceedings of the $3^{\text {rd }}$ Int. Conference on Applied Geophysics

Fraiha, S.G.C., Silva, J.B.C. (1994). Factor analysis of ambiguity in geophysics. Geophysics 59: 1083-1091

Griffiths, D.H., Barker, R.D. (1993). Two-dimensional resistivity imaging and modelling in areas of complex geology. Journal of Applied Geophysics, 29 (3-4), Pp. 211-226

Hazreek, Z.A.M., Rosli, S., Chitral, W.D., Fauziah, A., Azhar, A.T.S., Aziman, M., \& Ismail, B. (2015). Soil identification using field electrical resistivity method. Journal of Physics: Conference Series, 622(1). https://doi.org/10.1088/1742-6596/622/1/012030

Hickey, C., Schmitt, D., Sabatier, J., \& Riddle, G. (2009). Seismic measurements for detecting underground high-contrast voids. (Vol. 2). https://doi.org/10.4133/1.3176786 
Kong, T.B. (1999). Engineering properties of granitic soils and rocks of Penang Island, Malaysia. Geological Society of Malaysia, Bulletin 35, 1999, pp. 69-77

Loke, M.H. (2004). Tutorial: 2-D and 3-D electrical imaging surveys. 2004 Revised Edition, (July), 136

Mad Said, M.J., Zainorabidin, A., Madun, A. (2015). Soil velocity profile on soft soil using seismic refraction. Applied Mechanics and Materials, 773-774, 1549-1554. https://doi.org/10.4028/www.scientific.net/amm.773-774.1549

Moustafa, S.S.R., Ibrahim, E.H., Elawadi, E., Metwaly, M., Agami, N.A. (2013). Seismic refraction and resistivity imaging for assessment of groundwater seepage under a dam site, Southwest of Saudi Arabia. International Journal of Physical Sciences, 7(48), 6230-6239. https://doi.org/10.5897/IJPS12.401

Nur Amalina, M.K.A., Nordiana, M.M., Bery, A.A., Anuar, M.N.A., Maslinda, U., Sulaiman, N., Taqiuddin, Z.M. (2017). Application of 2-D resistivity imaging and seismic refraction method in identifying the structural geological contact of sedimentary lithologies. IOP Conference Series: Earth and Environmental Science, 62(1). https://doi.org/10.1088/1755-1315/62/1/012005

Nyabeze, P.K., Gwavava, O., Sekiba, M. (2018). Using electrical resistivity tomography (ERT) to delineate subsurface structures at Siloam hot spring in the Soutpansberg Basin, South Africa. Journal of Geography and Geology, 10(4), 19. https://doi.org/10.5539/jgg.v10n4p19

Riddle, G.I., Hickey, C.J., Schmitt, D.R. (2010). Subsurface tunnel detection using electrical resistivity tomography and seismic refraction tomography: A case study. Proceedings of The Symposium on the Application of Geophysics to Engineering and Environmental Problems, SAGEEP, 2(July 2015), 552-562. https://doi.org/10.4133/1.3445481

Saetang, K., Yordkayhun, S., Wattanasen, K. (2014). Detection of hidden faults beneath Khlong Marui fault zone using seismic reflection and 2-D electrical imaging. Science Asia, 40(6), 436-443. https://doi.org/10.2306/scienceasia1513-1874.2014.40.436

Solberg, I.L., Hansen, L., Rønning, J.S., Haugen, E.D., Dalsegg, E. \& Tønnesen, J. (2011). Combined geophysical and geotechnical approach to ground investigations and hazard zonation of a quick clay area, Mid Norway. Bulletin of Engineering Geology and the Environment, 71: 119-133

Sulaiman, N., Nordiana, M. M., Azwin, I. N., Taqiuddin, Z. M., Maslinda, U., Hisham, H., Nordiana, A. N. (2017). Integration of ground penetrating radar (GPR) and 2-D resistivity imaging methods for soil investigation. IOP Conference Series: Earth and Environmental Science, 62(1). https://doi.org/10.1088/1755-1315/62/1/012007

Yilmaz, O. (2001). Seismic data analysis: Processing, inversion, and interpretation of seismic data. Society of Exploration Geophysicists, $2^{\text {nd }}$ edition

Yusoh, R., Saad, R., Saidin, M., Muhammad, S.B., Anda, S.T. (2018). Integration of electrical resistivity and seismic refraction using combine inversion for detecting material deposits of impact crater at Bukit Bunuh, Lenggong, Perak. Journal of Physics: Conference Series, 995(1). https://doi.org/10.1088/1742-6596/995/1/012099 